\title{
KEWENANGAN PERADILAN TIPIKOR PASCA BERLAKUNYA UNDANG-UNDANG NO. 30 TAHUN 2014 TENTANG ADMINISTRASI PEMERINTAHAN
}

\author{
Mohammad Sahlan \\ Biro Hukum dan Organisasi Kementrian Kelautan dan Perikanan \\ J1. Medan Merdeka Timur No. 16 Gambir Jakarta Pusat \\ Email: con9.sahlan@gmail.com
}

\begin{abstract}
The purpose of this journal is to analyze the competency of the administrative court and the corruption court to examine and decide the element of abused of power in corruption act after enacment of the Government Administration Acts and the legal implication when the legislation policy provides the authority to examine and decide upon the matter to the two institutions court, and the arrangements to ideal concept in the future. This is a normative law research, using conceptual approach, statute approach and case approach. The result of this research shows that theoretically and practically the concept of "abuse of power" in the Government Administration Acts is the same with the concept of "abuse of power" in the Eradication Corruption Acts. Therefore, the corruption court and administrative court both have absolute competence to examine and decide abuse of power in corruption. However, based on the principle of "lex posteriori derogate legi priori", the authority to examine and decide the element of abuse of power as positions in corruption becomes the absolute competence of the administrative court. Legal implications of the policy legislation give authority to both courts to examine and decide the abuse of power. First, potential competency disputes between both court; second, create uncertainty mechanism for handling abuse of power in the corruption thus hampering efforts to eradicate corruption. Regulation in the future as problems of abuse of power as position does not dispute between the administrative court and the corruption court on judicial competency: First, the equation perspectives on the applicability of the Government Administration Acts, of the assessment of abuse of power in corruption. Second, reaffirming the absolute competence of the administrative court as arranged in the Government Administration Acts of assessment substance abuse of power in Article 3 of the Eradication Corruption Acts and arrangement in handling mechanisms (procedural law).
\end{abstract}

Key words: authority, court, abuse of power

\begin{abstract}
Abstrak
Jurnal ini bertujuan mengkaji kewenangan Peradilan TUN dan Peradilan Tipikor dalam memeriksa dan memutus unsur menyalahgunakan kewenangan dalam Tipikor pasca lahirnya UU Administrasi Pemerintahan, implikasi hukumnya ketika kebijakan legislasi memberikan kewenangan untuk memeriksa dan memutus masalah tersebut kepada dua lembaga Peradilan, serta konsep pengaturannya ke depan yang ideal. Kajian ini merupakan kajian hukum normatif, dengan menggunakan conceptual approach, statute approach, dan case approach. Hasil kajian menunjukkan secara teoritis dan praktis konsep "penyalahgunaan wewenang" dalam UU Administrasi Pemerintahan sama dengan konsep "menyalahgunakan kewenangan" dalam
\end{abstract}


UU Pemberantasan Tipikor. Karenanya, Peradilan Tipikor dan Peradilan TUN secara atributif sama-sama memiliki kompetensi absolut untuk memeriksa dan memutus penyalahgunaan kewenangan dalam Tipikor. Namun demikian, berdasarkan asas "lex posteriori derogate legi priori", kewenangan untuk memeriksa dan memutus unsur penyalahgunaan kewenangan karena jabatan dalam Tipikor menjadi kompetensi absolut Peradilan TUN. Implikasi hukum kebijakan legislasi yang memberikan kewenangan untuk memeriksa dan memutus penyalahgunaan kewenangan dalam Tipikor kepada dua lembaga peradilan, Pertama, berpotensi menimbulkan sengketa kewenangan mengadili antara kedua peradilan tersebut; Kedua, menimbulkan ketidakpastian mekanisme penanganan penyalahgunaan kewenangan dalam Tipikor sehingga menghambat upaya pemberantasan Tipikor. Pengaturan ke depan agar masalah penyalahgunaan kewenangan karena jabatan tidak menjadi sengketa kewenangan mengadili antara Peradilan Tipikor dan Peradilan TUN: Pertama, penyamaan perspektif mengenai keberlakuan UU Administrasi Pemerintahan, terhadap penilaian penyalahgunaan kewenangan dalam Tipikor. Kedua, menegaskan kompetensi absolut Peradilan TUN yang diatur dalam UU Administrasi Pemerintahan terhadap penilaian unsur penyalahgunaan kewenangan dalam Pasal $3 \mathrm{UU}$ Pemberantasan Tipikor dan melakukan penataan pada mekanisme penangannya (hukum acara).

kata kunci: kewenangan, peradilan, penyalahgunaan wewenang

\section{Latar Belakang}

Sebagai Negara hukum, ${ }^{1}$ Indonesia belum mampu mewujudkan social welfare sebagai tujuan Negara sesuai dengan amanah konstitusi. ${ }^{2}$ Salah satu hambatan utamanya adalah korupsi yang ditengarai sebagai penyebab utama keterpurukan bangsa ini. Upaya untuk memberantas korupsi bukanlah perkara mudah, penggolongan korupsi sebagai extra ordinary crime dengan upaya pemberantasan melalui extra ordinary enforcement, ternyata belum menunjukkan hasil yang signifikan. Data Corruption Perception Index 2014 yang dikeluarkan oleh Transparency International Indonesia (TII) menunjukkan hingga akhir 2014, korupsi di Indonesia masih relatif tinggi yaitu menempati posisi 117 dari 175 negara di dunia dengan skor 34 dari skala 0-100 (0 berarti sangat korup dan 100 berarti sangat bersih). ${ }^{3}$

Tumpang tindih peraturan perundangundangan di bidang pemberantasan Tindak Pidana Korupsi (Tipikor), merupakan salah satu hambatan utamanya. Padahal pembentukan peraturan perundang-undangan merupakan tahapan pertama dalam upaya pencegahan dan penanggulangan kejahatan dengan sarana "penal", yang perannya tidak kalah penting dengan tugas aparat penegak hukum/penerap hukum. ${ }^{4}$ Kebijakan

1 Pasal 1 ayat (3) Undang-Undang Dasar Negara Republik Indonesia 1945 pasca amandemen (selanjutnya disingkat UUD NRI 1945).

2 Salah tujuan Negara Indonesia tercantum dalam alinea keempat pembukaan UUD NRI 1945, yaitu "untuk memajukan kesejahteraan umum". Frasa "memajukan kesejahteraan umum" oleh sebagian ahli hukum dijadikan dasar untuk menyatakan Indonesia sebagai welfare state. Lihat Alfitri, "Ideologi Welfare State dalam Dasar Negara Indonesia: Analisis Putusan Mahkamah Konstitusi Terkait Sistem Jaminan Sosial Nasional", Jurnal Konstitusi Vol. 9, No. 3, (September 2012): 458.

3 Wahyudi Thohary, dkk., "Survey Persepsi Korupsi 2015", Laporan Penelitian. (Tanpa Tempat Terbit: Danish Royal Embassy, 2015), hlm. 4.

4 Mahmud Mulyadi, "Penanggulangan Tindak Pidana Korupsi Dalam Perspektif Criminal Policy (Corruption Reduction In Criminal Policy Perspective)", Jurnal Legislasi Indonesia Vol. 8, No. 2, (Jakarta: Direktorat Jenderal Perundang-undangan, Kementerian Hukum dan Hak Asasi Manusia, Juni 2011): 219. 
legislatif merupakan tahap awal yang paling strategis dari keseluruhan dimensi dari tahap fungsionalisasi/operasionalisasi/konkretisasi hukum pidana dan merupakan fundamen aplikasi dan tahap eksekusi. ${ }^{5}$ Kesalahan atau kelemahan dalam pembuatan kebijakan legislasi merupakan kesalahan strategis yang dapat menghambat upaya pencegahan dan penanggulangan kejahatan pada tahap aplikasi dan eksekusinya. ${ }^{6}$

Lahirnya Undang-Undang Nomor 30 Tahun 2014 tentang Administrasi Pemerintahan (UU Administrasi Pemerintahan) yang diundangkan pada tanggal 17 Oktober 2014 dan dimaksudkan untuk mengatur dan memperbaiki sistem reformasi birokrasi, ${ }^{7}$ sebagai sarana penanggulangan Tipikor melalui pendekatan pencegahan (preventif), ${ }^{8}$ merupakan contoh peraturan perundang-undangan terkait dengan pemberantasan Tipikor yang salah satu normanya bertentangan (conflict of norm) dengan salah satu norma dalam UU Nomor 31 Tahun 1999 tentang Pemberantasan Tindak Pidana Korupsi, sebagaimana telah diubah dengan UU Nomor 20 Tahun 2001 (UU
Pemberantasan Tipikor) ${ }^{9}$ dan UU Nomor 46 Tahun 2009 tentang Pengadilan Tindak Pidana Korupsi (UU Pengadilan Tipikor), ${ }^{10}$ yang merupakan instrumen hukum dalam upaya penanggulangan korupsi melalui pendekatan penindakan (represif).

Conflict of norm terjadi antara Pasal 5 dan Pasal 6 UU Pengadilan Tipikor jo. Pasal 3 UU Pemberantasan Tipikor dengan ketentuan Pasal 21 ayat (1) jo. Pasal 1 angka 18 jo. Pasal 17 UU Administrasi Pemerintahan, berkenaan dengan kompetensi absolut untuk memeriksa dan memutus unsur "menyalahgunakan kewenangan" karena jabatan dalam Tipikor, yang konsepnya oleh beberapa ahli hukum dipandang sama dengan konsep "penyalahgunaan wewenang” dalam UU Administrasi Pemerintahan yang kewenangan untuk memeriksa dan memutus masalah tersebut diberikan kepada Peradilan Tata Usaha Negara (Peradilan TUN).

Istilah wewenang yang lazim digunakan dalam Hukum Administrasi Negara (HAN), seringkali dipertukarkan dengan istilah kewenangan. ${ }^{11}$ Namun ada juga ahli hukum yang membedakannya. Ateng Syafrudin dan

5 Lilik Mulyadi, Kompilasi Hukum Pidana Dalam Perspektif Teoritis dan Praktik Peradilan, (Bandung: Mandar Maju, 2010), hlm. 88.

6 Chaerudin, dkk., Strategi Pencegahan \& Penegakan Hukum Tindak Pidana Korupsi, Cetakan Ke-2, (Bandung: Refika Aditama, 2009), hlm. 88.

7 Kementerian Pendayagunaan Aparatur Negara dan Reformasi Birokrasi, Naskah Akademik Rancangan Undang-Undang tentang Administrasi Pemerintahan, (Jakarta: Kemenpan RB, tanpa tahun), hlm. 8.

8 Lihat Penjelasan Umum UU Administrasi Pemerintahan, paragraf 10.

9 UU Pemberantasan TPK diundangkan pada tanggal 16 Agustus 1999, sedangkan perubahannya diundangkan pada tanggal 21 Nopember 2001.

10 UU Pengadilan TPK diundangkan pada tanggal 29 Oktober 2009.

11 Philiphus M. Hadjon, dkk., Hukum Administrasi dan Tindak Pidana Korupsi, Cetakan Ke-2, (Yogyakarta: Gajahmada University Press, 2012), hlm. 10. 
S. F. Marbun, ${ }^{12}$ termasuk yang membedakan antara keduanya, kewenangan (authority atau gezag) disebut sebagai kekuasaan formal, kekuasaan yang berasal dari kekuasaan yang diberikan oleh undang-undang, yang di dalamnya terdapat wewenang-wewenang, sehingga wewenang (competence atau bevoegdheid) hanyalah bagian tertentu saja (onderdeel) dari kewenangan.

Apabila dikaitkan dengan penyalahgunaan, maka terdapat perbedaan dalam penggunaan istilah wewenang dan kewenangan. Istilah yang digunakan dalam hukum pidana adalah "menyalahgunakan kewenangan" yang selalu dikaitkan dengan jabatan yang di miliki seseorang dan merupakan bestanddeel delict dalam Tipikor yang diatur Pasal 3 UU Pemberantasan Tipikor, ${ }^{13}$ yang merupakan kompetensi absolut Peradilan Tipikor sesuai ketentuan Pasal 5 dan Pasal 6 UU Pengadilan Tipikor.

Sedangkan istilah "penyalahgunaan wewenang", merupakan larangan bagi badan atau pejabat pemerintahan dan merupakan kompetensi absolut Peradilan TUN. ${ }^{14}$ Walaupun kompetensi tersebut dibatasi hanya terhadap keputusan dan/atau tindakan Pejabat Pemerintahan yang belum diproses pidana dan telah ada hasil pengawasan Aparat Pengawasan Intern Pemerintah (APIP). ${ }^{15}$
Terminologi “penyalahgunaan wewenang" dalam UU Administrasi Pemerintahan inilah yang dipandang sama dengan konsep "menyalahgunakan kewenangan" karena jabatan dalam UU Pemberantasan Tipikor, sehingga berpotensi menimbulkan sengketa kewenangan mengadili antara Peradilan Tipikor dan Peradilan TUN. Ada yang berpendapat lahirnya UU Administrasi Pemerintahan mengakibatkan kewenangan absolut untuk memeriksa dan memutus penyalahgunaan kewenangan dalam Tipikor beralih ke Peradilan TUN, namun ada juga yang berpendapat sebaliknya.

Untuk itulah topik mengenai kewenangan Peradilan Tipikor dan Peradilan TUN dalam memeriksa dan memutus unsur menyalahgunakan kewenangan dalam Tipikor pasca berlakunya UU Administrasi Pemerintahan layak untuk dikaji. Kajian difokuskan pada masalah tentang 1). Siapa yang berwenang memeriksa dan memutus unsur menyalahgunakan kewenangan dalam Tipikor pasca berlakunya UU Administrasi Pemerintahan? 2). Apa implikasi hukum kebijakan legislasi yang memberikan kewenangan memeriksa dan memutus unsur menyalahgunakan kewenangan dalam Tipikor kepada Peradilan Tipikor dan Peradilan TUN? 3). Bagaimana pengaturan ke depan agar

12 Ateng Syafrudin, "Menuju Penyelenggaraan Pemerintahan Negara yang Bersih dan Bertanggungjawab", Jurnal Pro Justitia IV, (Bandung: Universitas Parahyangan, 2000), hlm. 22.

13 Pasal 3 UU Pemberantasan TPK menyatakan "Setiap orang yang dengan tujuan menguntungkan diri sendiri atau orang lain atau suatu korporasi, menyalahgunakan kewenangan, kesempatan atau sarana yang ada padanya karena jabatan atau kedudukan yang dapat merugikan keuangan negara atau perekonomian negara, dipidana dengan pidana ...".

14 Lihat Pasal Pasal 17 jo. Pasal 21 ayat (1) jo. Pasal 1 angka 18 UU Administrasi Pemerintahan.

15 Lihat Pasal 2 Peraturan MARI Nomor 4 Tahun 2015 tentang Pedoman Beracara Dalam Penilaian Penyalahgunaan Wewenang. 
masalah penyalahgunaan kewenangan karena jabatan tidak menjadi sengketa kewenangan mengadili antara Peradilan Tipikor dan Peradilan TUN?

Kajian ini merupakan kajian hukum normatif, dengan menggunakan conceptual approach, statute approach, dan case approach. Bahan hukum yang digunakan bahan hukum primer, tersier, dan sekunder.

\section{Pembahasan}

\section{A. Kompetensi Absolut Untuk Memeriksa dan Memutus Unsur Menyalahgunakan Kewenangan Dalam Tipikor}

Untuk menentukan siapa yang berwenang untuk memeriksa dan memutus unusr menyalahgunakan kewenangan diantara Peradilan TUN dan Peradilan Tipikor, maka terlebih dahulu perlu ada kejelasan konsep mengenai istilah "penyalahgunaan wewenang" sebagai terminologi yang digunakan dalam UU Administrasi Pemerintahan (lazim digunakan dalam HAN) dan istilah "menyalahgunakan kewenangan" sebagai terminologi yang digunakan dalam UU Pemberantasan Tipikor (lazim digunakan dalam Hukum Pidana). Perlu dikaji apakah istilah "penyalahgunaan wewenang" merupakan konsep yang sama dengan istilah "menyalahgunakan kewenangan" atau sebaliknya.
Secara etimologis, penyalahgunaan dan menyalahgunakan berasal dari dua suku kata "salah guna". ${ }^{16}$ Ketika di beri prefiks "pe-" dan diberi sufiks “-an", maka "salah guna" menjadi “penyalahgunaan” dan berkedudukan sebagai noun yang berarti proses, cara, perbuatan menyalahgunakan; penyelewengan. Sedangkan "menyalahgunakan" berkedudukan sebagai verb setelah "salah guna" di tambahi prefiks "me-" dan sufiks "-kan", dan maknanya menjadi melakukan sesuatu tidak sebagaimana mestinya; menyelewengkan. Jadi kata "penyalahgunaan" dan "menyalahgunakan" merupakan 2 (dua) istilah yang berasal dari 2 (dua) suku kata yang sama "salah guna", maknanyapun tidak jauh berbeda yaitu penyelewengan atau menyelewengkan. "Penyalahgunaan" menunjuk pada proses, cara, perbuatannya, sedangkan "menyalahgunakan" menunjuk pada tindakan atau pelaksanaanya.

Istilah penyalahgunaan/menyalahgunakan dalam kepustakaan hukum Belanda dikenal dengan misbruik atau missbrauch dalam istilah hukum Jerman, ${ }^{17}$ atau misuse dan abuse dalam istilah Bahasa Inggris, ${ }^{18}$ yang maknanya tidak jauh berbeda dengan istilah dalam bahasa Indonesia, yaitu sebagai perbuatan dan/atau perkataan yang dilakukan secara salah atau untuk maksud yang salah/ diselewengkan atau berlebih-lebihan (berkenaan dengan perbuatan yang berkonotasi negatif).

Istilah "wewenang" dan "kewenangan"

16 KBBI, “Arti dari Salah Guna, Menyalahgunakan”, kbbi.web.id/ salah\%20guna.menyalahgunakan, diakses 8 Maret 2016.

17 Budi Parmono, "Penyalahgunaan Wewenang Dalam Tindak Pidana Korupsi di Indonesia", Disertasi Doktor Ilmu Hukum, (Malang: Fakultas Hukum UB, 2011), Dipublikasikan, hlm. 137.

18 Victoria Bull, Oxford Learner's Pocket Dictionary: Fourth Edition, (Oxford: Oxford University Press, 2012), hlm. 282. 
berasal dari kata "wenang" dan berbentuk kata benda (noun). Wewenang dimaknai sebagai 1. Hak dan kekuasaan untuk bertindak; kewenangan; 2. Kekuasaan membuat keputusan, memerintah, dan melimpahkan tanggung jawab kepada orang lain; 3. Huk fungsi yang boleh tidak dilaksanakan. Ketika di beri prefiks "ke-" dan diberi sufiks "-an" maka kata "wenang" menjadi "kewenangan" dan kedudukannya tetap sebagai kata benda (noun) yang berarti

1. Hal berwenang; 2. Hak dan kekuasaan yang dipunyai untuk melakukan sesuatu. ${ }^{19}$

Istilah wewenang dan kewenangan dalam bahasa Inggris dikenal dengan "authority" dan tidak ada pembedaan antara keduanya. Hal ini sama dengan istilah dalam bahasa Belanda, yang tidak membedakan istilah kewenangan dengan istilah wewenang. Istilah yang sering digunakan adalah bevoegdheid, meskipun ada istilah lain yang terjemahannya adalah kewenangan atau kompetensi yaitu bekwaamheid. ${ }^{20}$ Authority dalam Black's Law Dictionary, ${ }^{21}$ diartikan sebagai:

"Legal power; a right to command or to act; the right and power of public officers to require obedience to their orders lawfully issued in scope of their public duties."

Jadi secara terminologis, istilah "wewenang" dengan "kewenangan" tidak ada perbedaan substansial. Kedua istilah tersebut selalu di kaitkan dengan "hak dan kekuasaan untuk bertindak atau melakukan sesuatu".

Secara teoritis, wewenang merupakan istilah yang lazim dikenal dan digunakan dalam hukum administrasi, bahkan dalam kepustakaan Hukum Administrasi Belanda, masalah wewenang selalu menjadi bagian penting dan bagian awal dari Hukum Administrasi karena obyek Hukum Administrasi adalah wewenang pemerintahan (bestuurs bevoegdheid dalam konteks hukum publik). ${ }^{22}$ Istilah ini seringkali dipertukarkan dengan istilah kewenangan. ${ }^{23}$ F.A.M. Stroink dan J.G. Steenbeek menyebut kewenangan sebagai konsep inti dari Hukum Tata Negara dan Hukum Administrasi. ${ }^{24}$ Dalam banyak literatur istilah "wewenang" seperti disampaikan di atas banyak dipersamakan dengan istilah "kewenangan". Namun, ada pula ahli hukum yang juga membedakannya seperti yang disampaikan Ateng Syafrudin dan S.F Marbun diatas.

Secara yuridis, UU Administrasi Pemerintahan membedakan definisi wewenang dengan kewenangan. "Wewenang" didefinisikan sebagai "hak yang dimiliki oleh badan dan/atau pejabat pemerintahan

19 KBBI, “Arti dari Wenang”, kbbi.web.id/wenang, diakses 6 Desember 2015.

20 Susi Moeimam dan Hein Steinhauer, Kamus Belanda-Indonesia, (Jakarta: Gramedia Pustaka, 2005), hlm. 100.

21 Henry Campbell Black, Black’s Law Dictionary, Revised Fourth Edition, (ST. Paul, Minn.: West Publishing, 1968), hlm. 169

22 Philiphus M. Hadjon, dkk., Hukum Administrasi ..., op.cit., hlm. 10.

23 Ibid.

24 Ridwan HR, Hukum Administrasi Negara, Edisi Revisi, (Jakarta: RajaGrafindo Persada, 2014), hlm. 99. 
atau penyelenggara negara lainnya untuk mengambil keputusan dan/atau tindakan dalam penyelenggaraan pemerintahan." 25 Sedangkan "kewenangan" merupakan sebutan dari kewenangan pemerintahan yang dimaksudkan sebagai "kekuasaan badan dan/ atau pejabat pemerintahan atau penyelenggara negara lainnya untuk bertindak dalam ranah hukum publik." ${ }^{26}$

Walaupun secara yuridis UU Administrasi Pemerintahan membedakan definisi "wewenang" dan "kewenangan", pada hakekatnya keduanya merupakan hal yang sama karena sama-sama dilekatkan kepada "jabatan" yang yang dimiliki oleh badan dan/atau pejabat pemerintahan atau penyelenggara lainnya. Perbedaannya antara keduanya terletak pada luasan cakupannya, yang nampak pada kata "hak" ${ }^{27}$ pada definisi wewenang dan "kekuasaan"28 pada definisi kewenangan. Cakupan wewenang lebih sempit karena hanya dikaitkan dengan pengambilan keputusan dan/atau tindakan dalam penyelenggaraan pemerintahan. Sedangkan kewenangan cakupannya lebih luas karena berkaitan dengan tindakan dalam ranah hukum publik. Pembedaan tersebut menurut Yulius, hanya sebatas "spesies" dan "genus" dari sebuah jabatan. ${ }^{29}$ Jadi antara istilah wewenang dengan kewenangan tidak terdapat perbedaan konseptual. Pembedaan yang dilakukan oleh sebagian ahli hukum dan pembedaan definisi yuridis lebih kepada luasan cakupan antara wewenang dengan kewenangan, bukan pada substansinya.

"Penyalahgunaan wewenang" merupakan istilah yang lahir dari doktrin HAN dan lazim digunakan dalam ranah hukum tersebut. "Penyalahgunaan wewenang" dalam konsep HAN selalu diparalelkan dengan konsep detournament de pouvoir dalam sistem hukum Prancis atau abuse of power/misuse of power dalam istilah bahasa Inggris. ${ }^{30}$ Secara historis, konsep "detournament de pouvoir" pertama kali muncul di Prancis dan merupakan dasar pengujian lembaga peradilan administrasi negara terhadap suatu tindakan pemerintahan dan dianggap sebagai asas hukum yang merupakan bagian dari "de principes generaux du droit". Conseil d'Etat adalah lembaga peradilan pertama yang menggunakannya sebagai alat uji,

25 Lihat ketentuan Pasal 1 angka 4 UU Administrasi Pemerintahan.

26 Lihat ketentuan Pasal 1 angka 5 UU Administrasi Pemerintahan.

27 "hak" dalam konteks hukum menurut Kamus Besar Bahasa Indonesia dimaknai sebagai "wewenang menurut hukum”. Lihat KBBI, “Arti dari Hak”, kbbi.web.id/hak, diakses 14 Maret 2016.

28 "kekuasaan" menurut Kamus Besar Bahasa Indonesia dalam konteks hukum dimaknai sebagai $\sim$ eksekutif Huk kekuasaan (wewenang) untuk menjalankan undang-undang; legislatif Huk kekuasaan untuk membuat (membentuk) undang-undang; perundang-undangan kekuasaan legislatif; yudikatif kekuasaan untuk mengawasi pelaksanaan undang-undang." Lihat KBBI, “Arti dari Kuasa”, kbbi.web.id/kuasa, diakses 14 Maret 2016.

29 Yulius, "Perkembangan Pemikiran dan Pengaturan Penyalahgunaan Wewenang di Indonesia (Tinjauan Singkat Dari Perspektif Hukum Administrasi Negara Pasca Berlakunya Undang-Undang Nomor 30 Tahun 2014)", Jurrnal Hukum dan Peradilan, Badan Penelitian dan Pengembangan Hukum dan Peradilan Mahkamah Agung RI Vol. 04, No. 3, (November 2015): 373.

30 Philipus M. Hadjon, dkk., Hukum Administrasi dan..., op.cit., hlm. 21-22. 
yang kemudian diikuti oleh negara-negara lain seperti Belanda dan Indonesia. Pejabat pemerintahan dinyatakan melanggar prinsip détournement de pouvoir, manakala tujuan dari keputusan yang dikeluarkan atau tindakan yang dilakukan bukan untuk kepentingan atau ketertiban umum tetapi untuk kepentingan pribadi si pejabat (termasuk keluarga atau rekannya). ${ }^{31}$

Secara yuridis, tidak ada definisi penyalahgunaan wewenang. UU Administrasi Pemerintahan hanya mengatur tentang larangan penyalahgunaan wewenang dan tiga spesies larangan penyalahgunaan wewenang yang meliputi larangan melampaui wewenang, larangan mencampuradukkan wewenang dan larangan bertindak sewenang-wenang. ${ }^{32}$ Larangan melampaui wewenang terjadi ketika keputusan dan/atau tindakan Badan dan/atau Pejabat Pemerintahan dilakukan dengan "a). melampaui masa jabatan atau batas waktu berlakunya wewenang; b). melampaui batas wilayah berlakunya wewenang; dan/atau c). bertentangan dengan ketentuan peraturan perundang-undangan.” Sedangkan larangan mencampuradukkan wewenang terjadi apabila keputusan dan/atau tindakan tersebut dilakukan "a). di luar cakupan bidang atau materi wewenang yang diberikan; dan/atau b). bertentangan dengan tujuan wewenang yang diberikan." Sementara keputusan dan/ atau tindakan yang dilakukan Badan dan/atau Pejabat Pemerintahan dikategorikan tindakan sewenang-wenang manakala dilakukan “a). tanpa dasar kewenangan; dan/atau b). bertentangan dengan Putusan Pengadilan yang berkekuatan hukum tetap." ${ }^{33}$

Penyalahgunaan wewenang dalam hukum positif Indonesia, dijadikan alasan (dasar) gugatan bagi seseorang atau badan hukum perdata yang merasa kepentingannya dirugikan oleh suatu Keputusan TUN (pihak Penggugat). ${ }^{34}$ Dalam praktek hukum pidana, khususnya pada Peradilan Tipikor, ketentuan tersebut seringkali digunakan untuk menjelaskan unsur "menyalahgunakan kewenangan" yang terdapat dalam ketentuan Pasal 3 UU Pemberantasan Tipikor melalui penafsiran ekstensif dengan pendekatan doktrin otonomi hukum pidana. ${ }^{35}$ "Menyalahgunakan kewenangan" adalah salah satu unsur penting dalam Tipikor yang berkaitan dengan jabatan bahkan merupakan bagian inti delik (bestanddeel delict). ${ }^{36}$ Selain itu, menyalahgunakan kewenangan merupakan species delict dari unsur melawan

31 Yulius, "Perkembangan Pemikiran ..., op.cit.., hlm. 364.

32 Lihat ketentuan Pasal 17 UU Administrasi Pemerintahan.

33 Lihat ketentuan Pasal 18 ayat (1), ayat (2) dan ayat (3) UU Administrasi Pemerintahan.

34 Lihat Pasal 53 ayat (2) huruf b UU Nomor 5 Tahun 1986 tentang Peradilan TUN.

35 Lihat Putusan MARI Nomor: 14/Pid.Sus /2012/PN.AB. dengan Terdakwa Edi Tri Sukmono, SH. Alias Edi dan Putusan MARI Nomor: 03/PID.SUS/TIPIKOR/2013/PN.PBR. dengan Terdakwa Amril Daud.

36 Menurut yurisprudensi MARI, unsur "menyalahgunakan kewenangan” dalam ketentuan Pasal 3 UU Pemberantasan TPK merupakan inti delik dari pasal tersebut, sehingga dalam penerapannya untuk melakukan pemidanaan terhadap terdakwa korupsi berdasarkan ketentuan Pasal 3 ini, unsur "menyalahgunakan kewenangan" harus terpenuhi. Lihat Putusan MARI Nomor 1485K/Pid.Sus/2013, tanggal 2 Oktober 2013, hlm. 132. 
hukum sebagai genus delict. ${ }^{37}$

Secara yuridis,

mengenai

menyalahgunakan kewenangan karena

jabatan, UU Pemberantasan Tipikor tidak

memberikan definisi atau pengertian

tersendiri. Istilah "menyalahgunakan

kewenangan" justru ditemukan dalam UU

Administrasi Pemerintahan yaitu sebagai bagian dari Asas-asas Umum Pemerintahan yang Baik (AUPB), yang diantara berupa "asas tidak menyalahgunakan kewenangan". ${ }^{38}$

Pada bagian penjelasan dinyatakan bahwa yang dimaksud oleh asas tersebut adalah:

"asas yang mewajibkan setiap Badan dan/atau Pejabat Pemerintahan untuk tidak menggunakan kewenangannya bagi kepentingan pribadi atau kepentingan yang lain dan tidak sesuai dengan tujuan pemberian kewenangan tersebut, tidak melampaui, tidak menyalahgunakan, dan/atau tidak mencampuradukkan kewenangan.”

Apabila dicermati, unsur-unsur yang terdapat dalam penjelasan "asas tidak menyalahgunakan kewenangan" isinya sama dengan tiga spesies larangan penyalahgunaan wewenang dan yang terpenting dalam penjelasan asas tersebut, unsur penyimpangan tujuan (asas spesialitas) yang dalam HAN selama ini selalu diidentikkan dengan pengertian "penyalahgunaan wewenang", juga dimasukkan dalam penjelasan asas "tidak menyalahgunakan kewenangan".

Pengertian "menyalahgunakan kewenangan" yang disampaikan oleh para ahli hukum (khususnya ahli Hukum Pidana ternyata tidak jauh berbeda dengan pengertian “penyalahgunaan wewenang” yang ada dalam konsep HAN. Pengertian "menyalahgunakan kewenangan" ditekankan pada penyimpangan tujuan dari pemberian kewenangan tersebut (penyimpangan asas spesialitas), walapun pada beberapa pengertian ditambahkan dengan unsur lain seperti penyalahgunaan prosedur dan perbuatan yang dilakukan tanpa wewenang/kewenangan. Tetapi unsur penyimpangan tujuan yang selama ini identik dengan pengertian "penyalahgunaan wewenang" dalam HAN selalu disematkan terhadap pengertian "menyalahgunakan kewenangan". 39

Praktik peradilan pidana, khususnya Peradilan Tipikor juga telah absorbsi pengertian "penyalahgunaan wewenang" kedalam pengertian "menyalahgunakan kewenangan" melalui pendekatan ekstensif dengan menggunakan doktrin otonomi hukum pidana dari H.A. Demeersemen. Hal tersebut telah diterima dan dianggap sebagai hal yang jamak oleh kalangan praktisi hukum pidana (ahli hukum pidana, advokad, dan

37 Abdul Latif, Hukum Administrasi Dalam Tindak Pidana Korupsi, (Jakarta: Prenada Media Group, 2014), hlm. 41.

38 Lihat ketentuan Pasal 10 ayat (1) huruf e UU Administrasi Pemerintahan beserta penjelasannya.

39 Adami Chazawi, Hukum Pidana Materiil dan Formil Korupsi di Indonesia, (Malang: Bayumedia, 2005), hlm. 66-68. Lihat juga R. Wiyono, Pembahasan Undang-Undang Pemberantasan Tindak Pidana Korupsi, Edisi Kedua, (Jakarta: Sinar Grafika, 2012), hlm. 45. 
hakim) dan sudah menjadi yurisprudensi. ${ }^{40}$ Diantaranya Putusan MARI Nomor 977K/ PID/2004, tanggal 10 Juni 2005, Putusan MARI Nomor 979K/PID/2004, tanggal 10 Juni 2005, Putusan Mahkamah Agung Republik Indonesia (MARI) Nomor: 1485K/ Pid.Sus/2013, tanggal 2 Oktober 2013, dan Putusan Hakim Pengadilan Tanjung Pinang Nomor: 3/Pid.Sus-Tipikor/2015/PN.Tpg, tanggal 11 Juni 2015.

Berdasarkan pembahasan di atas secara teoritis dan praktis, dapat dinyatakan bahwa konsep "penyalahgunaan wewenang" dengan konsep "menyalahgunakan kewenangan" adalah sama, sehingga Peradilan Tipikor dan Peradilan TUN sama memiliki kewenangan atributif untuk memeriksa dan memutus masalah menyalahgunakan kewenangan karena jabatan dan hal ini berpotensi menimbulkan titik singgung kewenangan mengadili antar dua lembaga peradilan tersebut.

Secara teori, menurut ilmu perundangundangan ketika terjadi antinomi hukum, maka dapat diselesaikan dengan asas preferensi hukum, yang terdiri dari 3 (tiga) asas, yaitu: lex superior derogat legi inferiori; lex specialis derogat legi generalis; dan lex posteriori derogate legi priori. ${ }^{41}$ Asas preferensi yang dapat diterapkan dalam konteks terjadinya conflict of norm antara ketentuan dalam UU Pengadilan Tipikor jo. UU Pemberantasan Tipikor dengan ketentuan dalam UU Administrasi Pemerintahan adalah asas hukum "lex posteriori derogate legi priori", karena pertentangan yang ada, terjadi antara ketentuan yang termuat dalam undang-undang yang sebelumnya telah ada dengan ketentuan yang terdapat dalam undang-undang yang baru dibentuk..$^{42}$ Dimana ketiga undang-undang tersebut kedudukannya selevel undang-undang dan substansi yang diatur sama, yaitu mengenai penanganan masalah penyalahgunaan wewenang/ menyalahgunakan kewenangan. Oleh karena itu, kewenangan untuk memeriksa dan memutus penyalahgunaan kewenangan dalam Tipikor merupakan kompetensi absolut Peradilan TUN, karena UU Administrasi Pemerintahan diundangkan setelah UU Pemberantasan Tipikor dan UU Peradilan Tipikor. $^{43}$

\section{B. Implikasi Hukum}

Adanya asas preferensi yang secara teoritis seharusnya dapat menyelesaikan persoalan antinomi hukum terkait kewenangan mengadili penyalahgunaan kewenangan

40 Lihat juga Putusan MARI Nomor 977K/PID/2004, tanggal 10 Juni 2005, hlm. 196-197. Lihat juga Putusan MARI Nomor 979K/PID/2004, tanggal 10 Juni 2005, hlm. 86-88.

41 Wasis Susetio, "Disharmoni Peraturan Perundang-Undangan Di Bidang Agraria”, Jurnal Lex Jurnalica, Vol. 10, No. 3, (Desember 2013):145.

42 Sidharta, Penemuan Hukum Melalui Putusan Hakim, Makalah, disampaikan dalam Seminar Nasional Pemerkuatan Pemahaman Hak Asasi Manusia Untuk Hakim Seluruh Indonesia, yang diselenggarakan oleh Komisi Yudisial RI, PUSHAM UII, dan Norsk Senter For Menneskerettigheter Norwegian Centre For Human Rights, (Medan: Hotel Grand Angkasa, 2011), hlm. 10.

43 UU Pengadilan TPK diundangkan pada tanggal 29 Oktober 2009, sedangkan UU Administrasi Pemerintahan diundangkan pada tanggal 17 Oktober 2014. 
dalam Tipikor, dalam praktek sepertinya akan menemui banyak persoalan. Hal ini mungkin terjadi karena belum ada persamaan perspektif dalam melihat keberlakuan UU Administrasi Pemerintahan terhadap kewenangan memeriksa dan memutus unsur "menyalahgunakan kewenangan" dalam Tipikor. Para penegak hukum (utamanya Hakim Agung pada MARI sebagai pemegang kewenangan absolut tingkat pertama dan terakhir dalam memeriksa dan memutus semua sengketa tentang kewenangan mengadili antar lingkungan peradilan) belum padu dalam menilai adanya kontradiksi norma terkait permasalahan penyalahgunaan wewenang/ menyalahgunakan kewenangan ini.

Andhi Nirwanto, Wakil Jaksa Agung, berpendapat konsepsi "penyalahgunaan wewenang" dalam UU Administrasi Pemerintahan berbeda dengan konsepsi "menyalahgunakan kewenangan" dalam UU Pemberantasan Tipikor. UU Administrasi Pemerintahan telah membedakan secara jelas pengertian "wewenang" dan "kewenangan", sehingga antara keduanya tidak perlu dipertentangkan. Wewenang yang identik dengan "hak" berimplikasi hukum penggunaan wewenang dibatalkan atau tidak sah, sedangkan kewenangan identik dengan "kekuasaan" selain berimplikasi administrasi dan TUN juga berakibat Hukum Pidana. ${ }^{44}$ Pendapat senada disampaikan oleh Yulius,
Hakim Agung pada Kamar TUN MARI, menyatakan tidak ada tumpang tindih antara norma penyalahgunaan wewenang dalam UU Administrasi Pemerintahan dan UU Pengadilan Tipikor jo. UU Pemberantasan Tipikor, karena masing-masing memiliki kompetensi absolut yang berbeda. Tidak tepat apabila PTUN menguji penyalahgunaan wewenang yang actus reus (tindak pidana yang dilakukan) dan mens rea (sikap-batin atau niatnya) kesalahan bersifat kepidanaan. Fungsi sebagai hakim pidana tidak boleh dijalankan oleh Hakim Peradilan TUN. Demikian pula sebaliknya, hakim pidana tidak dapat mendudukan dirinya sebagai Hakim TUN. Kedua lembaga peradilan tersebut mempunyai prinsip-prinsip hukum masingmasing yang tidak saling bertentangan, akan tetapi dapat saling mengisi. ${ }^{45}$

Pendapat berbeda disampaikan oleh Santer Sitorus, Hakim Tinggi Pengadilan Tinggi TUN Surabaya, yang memandang unsur "menyalalahgunakan kewenangan" dalam UU Pemberantasan Tipikor sama dengan "penyalahgunaan wewenang" dalam UU Administrasi Pemerintahan, sehingga ketika terjadi permohonan pengujian ada tidaknya unsur penyalahgunaan wewenang dalam keputusan dan/atau tindakan badan dan/atau pejabat pemerintahan, maka proses penegakan hukum pidana yang akan dan/atau sedang berjalan untuk sementara waktu tertunda. ${ }^{46}$

\footnotetext{
44 Andhi Nirwanto D. Arah Pemberantasan Korupsi Ke Depan(Pasca Undang-Undang Administrasi Pemerintahan) disampaikan dalam Seminar Nasional dalam rangka H.U.T. IKAHI Ke-62 dengan tema "Undang-Undang Administrasi Pemerintahan, Menguatkan atau Melemahkan Upaya Pemberantasan Korupsi”, (Jakarta: Hotel Mercure Ancol, 2015), hlm. 16-19.
}

45 Yulius, "Perkembangan Pemikiran ...”, op.cit., hlm. 379. 
Pendapat ini diterima juga oleh Supandi, Hakim Agung pada Kamar TUN MARI, yang menyatakan ketentuan dalam Pasal 21 ayat (1) UU Administrasi Pemerintahan dianggap telah mencabut kewenangan yang dimiliki penyidik dalam melakukan penyidikan terjadinya penyalahgunaan wewenang yang dilakukan oleh seorang tersangka selaku pejabat pemerintahan, karena hal tersebut seharusnya menjadi objek untuk diuji terlebih dahulu di Peradilan TUN. ${ }^{47}$ Dalam hal putusan Pengadilan TUN yang sudah berkekuatan hukum tetap menyatakan tidak ada penyalahgunaan wewenang, maka menurut Zudan Arif Fakrullah (anggota Tim Penyusun UU Administrasi Pemerintahan), pejabat bersangkutan tidak dapat diperiksa dalam konteks hukum pidana, perdata, maupun administrasi. Pintu bagi aparat penegak hukum untuk membawa ke ranah pidana ataupun ranah hukum lainnya baru terbuka ketika Pengadilan TUN memutus sebaliknya. ${ }^{48} \mathrm{Hal}$ ini menurut Krisna Harahap, Hakim Agung Ad Hoc Tipikor MARI merupakan langkah nyata menghambat upaya pemberantasan korupsi. ${ }^{49}$ Jadi, penerapan asas preferensi dalam konteks penyelesaian sengketa kewenangan dalam memeriksa dan memutus unsur "menyalahgunakan kewenangan" karena jabatan dalam Tipikor pada prakteknya sepertinya masih akan menemui kesulitan, dan belum dapat menyelesaikan potensi sengketa kewenangan mengadili penyalahgunaan kewenangan dalam Tipikor antara Peradilan Tipikor dengan Peradilan TUN.

Selain berpotensi menimbulkan sengketa kompetensi absolut antara Peradilan Tipikor dan Peradilan TUN, perbedaan perspektif mengenai keberlakuan undangundang UU Administrasi Pemerintahan tersebut, berdampak pada ketidakpastian mekanisme penanganan dugaan perbuatan menyalahgunakan kewenangan karena jabatan dalam Tipikor, dimana dalam praktiknya hal ini kemudian dijadikan jalan oleh tersangka dan/atau terdakwa korupsi untuk melakukan berbagai eksperimen hukum guna lolos dari jeratan hukum.

Banyak yang berpendapat bahwa jika selama ini seorang pejabat ditetapkan sebagai tersangka korupsi langsung diperiksa di Peradilan Umum (Peradilan

46 Santer Sitorus, "Penyelesaian Sengketa Administrasi Pemerintahan Berdasarkan UU Nomor 30 Tahun 2014 tentang Administrasi Pemerintahan" Slide Presentasi (PPT), disampaikan dalam Sosialisasi Undang-undang Nomor 30 Tahun 2014 tentang Administrasi Pemerintahan, (Jakarta: KemenPAN RB, 2015), hlm. 7 dan hlm. 12 .

47 Lihat Fathudin, “Tindak Pidana Korupsi (Dugaan Penyalahgunaan Wewenang) Pejabat Publik (Perspektif Undang-Undang Nomor 30 Tahun 2014 tentang Administrasi Pemerintahan)", Jurnal Cita Hukum Vol. II, No. 1, (Juni 2015): 129, ISSN: 2356-1440.

48 Zudan Arif Fakrullah, Tindakan Hukum Bagi Aparatur Penyelenggara Pemerintahan, Makalah, disampaikan dalam Seminar Nasional dalam rangka H.U.T. IKAHI Ke-62 dengan tema "Undang-Undang Administrasi Pemerintahan, Menguatkan atau Melemahkan Upaya Pemberantasan Korupsi. (Jakarta: Hotel Mercure Ancol, 2015), hlm. 13.

49 Detik.com, "UU Administrasi Pemerintahan Dinilai Mengudeta Pemberantasan Korupsi”, http://news.detik. $\mathrm{com} /$ berita/2873765/uu-administrasi-pemerintahan-dinilai-mengudeta-pem-berantasan-korupsi, diakses 28 Februari 2016. 
Tabel 1. Alur Penanganan Tipikor Karena Menyalahgunakan Kewenangan Berdasarkan UU Pemberantasan Tipikor, UU KPK, UU Pengadilan Tipikor, dan KUHAP

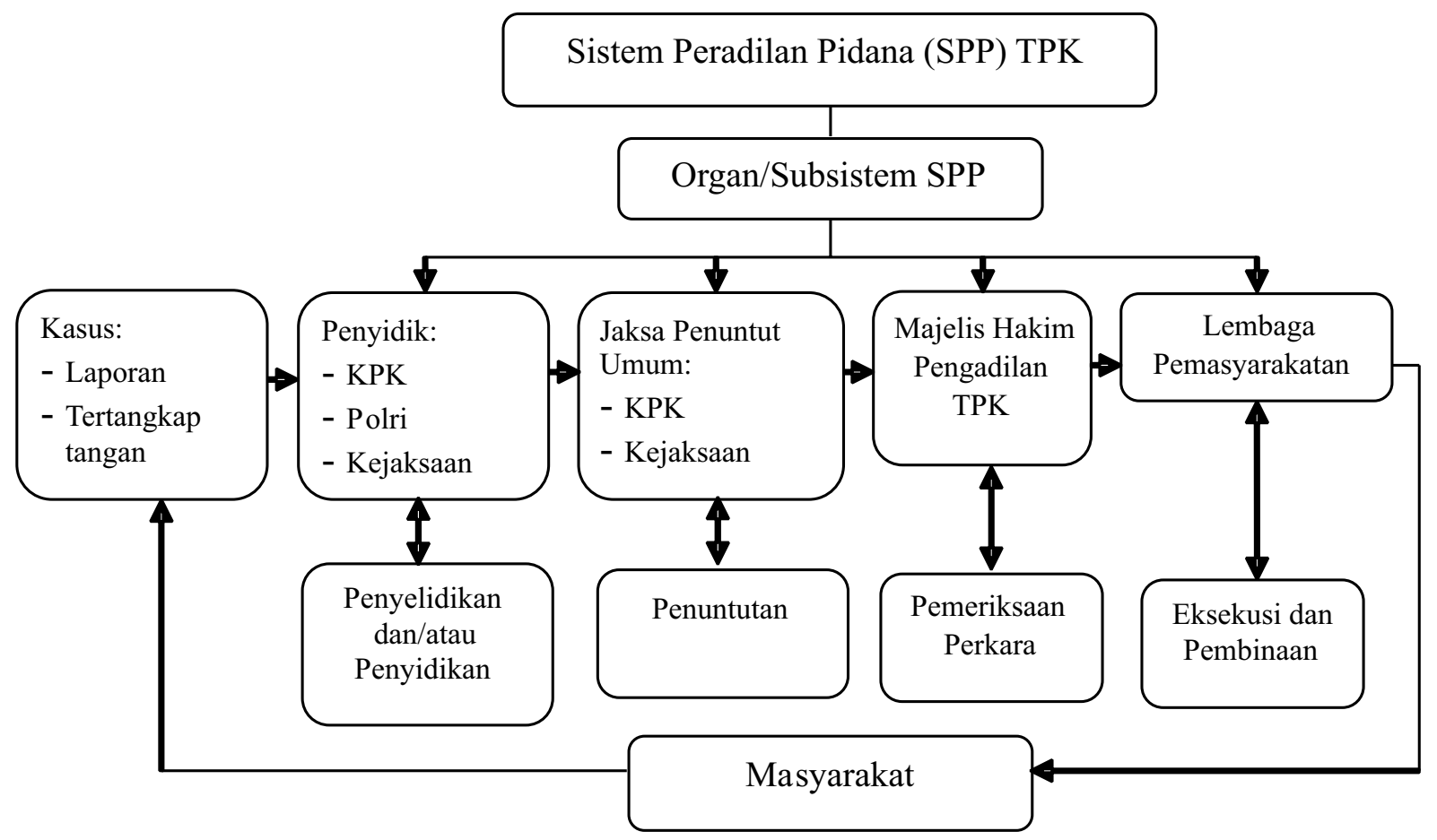

Sumber: Bahan Hukum Primer, diolah, 2016

Tipikor), kini dengan ketentuan Pasal 21 dalam hukum pidana, di mana keberadaan ayat (1) jo. Pasal 1 angka 18 jo. Pasal 17 UU pengaturan sanksi pidana harus diletakkan Administrasi Pemerintahan, maka pejabat atau diposisikan sebagai sanksi terakhir. ${ }^{51}$ yang bersangkutan dapat mengajukan Hal ini ditegaskan dalam Instruksi Presiden permohonan kepada Peradilan TUN terlebih dahulu untuk memeriksa dan memastikan ada atau tidak adanya unsur penyalahgunaan wewenang dalam keputusan dan/atau tindakan yang telah diambil, dan proses penegakan hukum pidana sementara waktu ditunda. ${ }^{50}$ Adanya mekanisme pengujian ada atau tidak adanya unsur penyalahgunaan wewenang melalui Peradilan TUN, dianggap inheren dengan asas ultimum remedium

RI Nomor 1 Tahun 2016 tentang Percepatan Pelaksanaan Proyek Strategis Nasional, yang menginstruksi-kan kepada Jaksa Agung dan Kapolri untuk mendahulukan proses administrasi pemerintahan sesuai ketentuan UU Administrasi Pemerintahan sebelum melakukan penyidikan atas laporan masyarakat yang menyangkut penyalahgunaan wewenang dalam pelaksanaan Proyek Strategis Nasional. Presiden juga menginstruksikan agar laporan

50 Santer Sitorus, "Praktek Peradilan Penyelesaian Sengketa Administrasi Pemerintahan Berdasarkan UU Nomor 30 Tahun 2014 tentang Administrasi Pemerintahan", Slide Presentasi (PPT), disampaikan dalam Colloqium Membedah Undang-undang Nomor 30 Tahun 2014 tentang Administrasi Pemerintahan, (Surabaya: Garden Palace, 2015), hlm. 6.

51 Lihat Fathudin, “Tindak Pidana Korupsi...”, loc.cit., hlm. 130. 
Tabel 2. Alur Penanganan Tipikor Karena Menyalahgunakan Kewenangan Karena Pasca Berlakunya UU Administrasi Pemerintahan

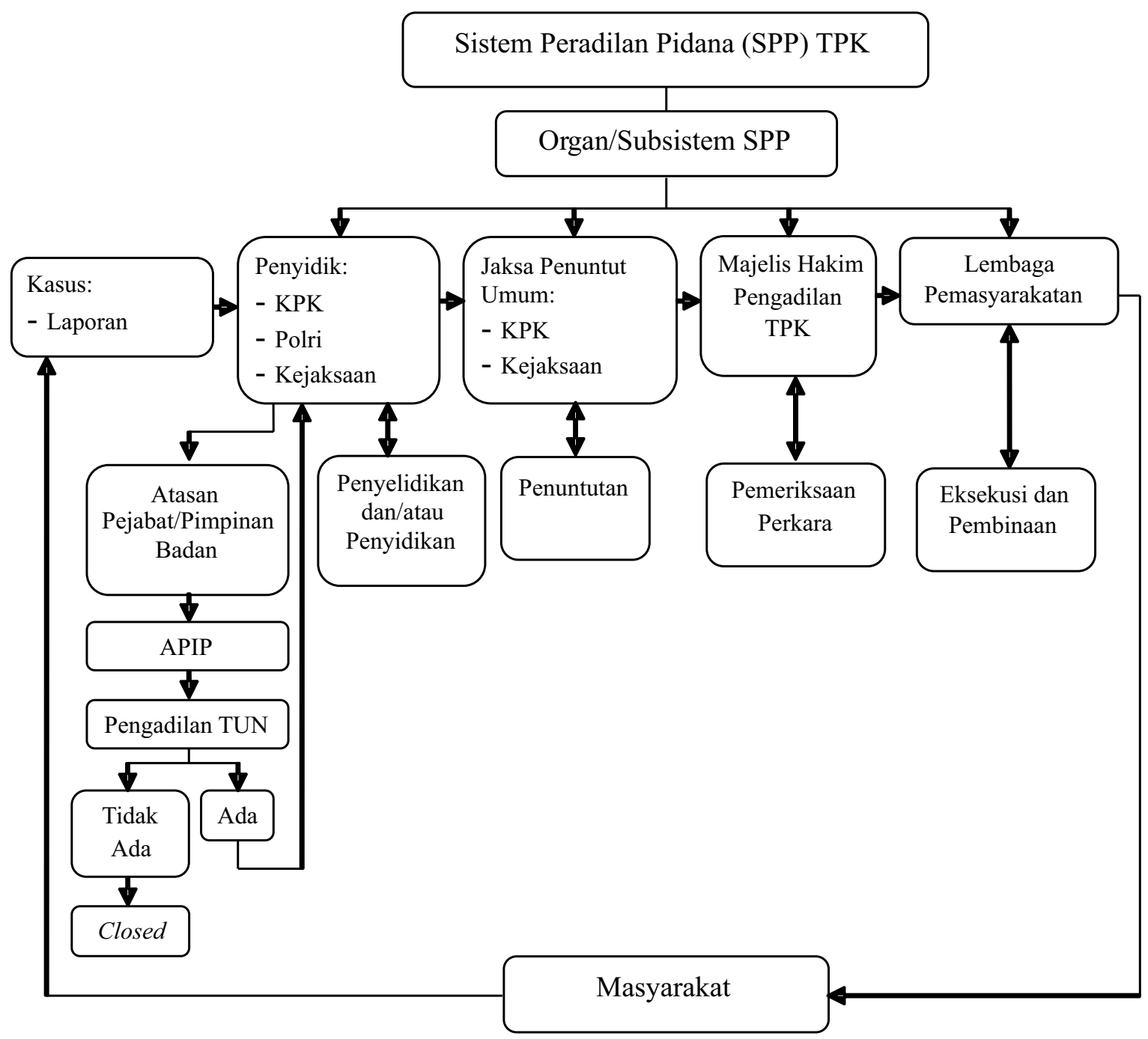

\section{Sumber: Bahan Hukum Primer, diolah, 2016}

masyarakat yang diterima oleh Kejaksaan Agung atau Polri mengenai penyalahgunaan wewenang dalam pelaksanaan Proyek Strategis Nasional diteruskan/disampaikan kepada pimpinan kementerian/lembaga atau pimpinan Pemerintah Daerah untuk dilakukan pemeriksaan dan tindak lanjut penyelesaian, termasuk dalam hal diperlukan adanya pemeriksaan oleh APIP.
UU Administrasi Pemerintahan juga dijadikan dasar oleh tersangka pelaku Tipikor menyalahgunakan kewenangan karena jabatan untuk melakukan praperadilan ke Peradilan Umum seperti yang dilakukan oleh R. H. Ilham Arief Sirajuddin, MM, mantan Walikota Makassar selaku Pemohon dan KPK selaku Termohon. ${ }^{52}$ Permohonan tersebut diterima oleh Hakim yang memeriksa Praperadilan

52 Lihat Putusan Pengadilan Negeri Jakarta Selatan Nomor: 32/Pid.Prap/2015/PN.Jkt.Sel., tanggal 12 Mei 2015 , hlm. 93-95. 
tersebut, walaupun putusannya kemudian tidak dilaksanakan oleh KPK, sehingga yang bersangkutan kembali mengajukan Praperadilan dengan salah satu alasannya adalah ketentuan dalam UU Administrasi Pemerintahan sebagaimana telah diuraikan di atas, namun di tolak oleh Hakim yang memeriksa dan memutus Praperadilan kedua. $^{53}$

Selain dijadikan dasar untuk mengajukan Praperadilan, yang unik UU Administrasi Pemerintahan, justru dijadikan dasar untuk melawan tindakan hukum pro justitia yang dilakukan oleh penegak hukum, dimana tindakan pro justitia tersebut dianggap sebagai tindakan penyalahgunaan wewenang karena tidak dilakukan berdasarkan UU Administrasi Pemerintahan. Contoh kasusnya, adalah permohonan pengujian kewenangan yang diajukan oleh Kepala Biro Keuangan Daerah Provinsi Sumatera Utara, karena yang bersangkutan tidak terima dipanggil oleh Kepala Kejaksaan Tinggi Sumatera Utara untuk dimintai keterangan berkenaan dengan dugaan Tipikor terkait dengan Dana Bansos di Provinsi Sumatera Utara berdasarkan Surat Panggilan Permintaan Keterangan Nomor: B-473/N.2.5/Fd.1/03/2015, tanggal 31 Maret 2015. Permohonan tersebut ternyata dikabulkan oleh Majelis Hakim Pengadilan TUN Medan walaupun kemudian, pada tingkat banding putusan tersebut dianulir oleh
Pengadilan Tinggi TUN Medan dengan alasan Pengadilan TUN Medan tidak berwenang secara absolut untuk memeriksa perkara tersebut. ${ }^{54}$ Selain itu, Putusan Pengadilan TUN Medan tersebut disinyalir dilakukan dengan kecurangan karena Majelis Hakim yang memeriksa perkara tersebut ternyata menerima suap dari kuasa hukum Pemohon.

Adanya permohonan Praperadilan dan permohonan pengujian kewenangan dengan dasar UU Administrasi Pemerintahan yang sempat diterima, walaupun kemudian dianulir padaupayahukumberikutnya,merupakanbukti nyata bahwa UU Administrasi Pemerintahan telah menimbulkan ketidakpastian mekanisme penanganan Tipikor sehingga menghambat upaya pemberantasan Tipikor.

\section{Pengaturan Yang Ideal Ke Depan}

Pada pembahasan sebelumnya, telah disampaikan bahwa potensi sengketa kewenangan mengadili (absolute competentie) antara Peradilan Tipikor dan Peradilan TUN masih mungkin terjadi, karena dalam praktiknya asas preferensi hukum belum mampu menyelesaikan conflict of norm yang ada. Persoalan ini terjadi karena belum adanya kesatuan perspektif dalam melihat keberlakuan UU Administrasi Pemerintahan terhadap penilaian penyalahgunaan kewenangan dalam Tipikor. Perbedaan perspektif ini berdampak pula pada ketidakpastian mekanisme penanganan masalah tersebut.

53 Lihat Putusan Pengadilan Negeri Jakarta Selatan Nomor: 55/Pid.Prap/2015/PN.Jkt.Sel., tanggal 9 Juli 2015 , hlm. 17 dan hlm. 93.

54 Lihat Putusan Pengadilan Tinggi TUN Medan Nomor 176/B/2015/PT TUN-MDN, tanggal 21 Desember 2015. 
Pihak yang berpendapat bahwa keberlakuan UU Administrasi Pemerintahan tidak ada pengaruhnya terhadap kewenangan Peradilan Tipikor dalam menilai unsur menyalahgunakan kewenangan dalam Tipikor, mekanisme penanganannya tetap merujuk pada ketentuan dalam UU Pemberantasan Tipikor, UU KPK, dan UU Pengadilan Tipikor yang selama ini sudah berjalan, yaitu ketika terjadi dugaan Tipikor menyalahgunakan kewenangan karena jabatan (baik berdasarkan adanya laporan atau tertangkap tangan), Penyidik (KPK, Polri, dan Kejaksaan) dapat langsung melakukan penyelidikan dan penyidikan untuk memastikan adanya Tipikor tersebut dan menemukan tersangkanya, kemudian ketika telah didapatkan alat bukti yang cukup, perkara dapat dilimpahkan ke penuntut umum (penuntuk umum pada KPK atau penuntut umum pada Kejaksaan) untuk dilakukan penuntutan atau dilimpahkan ke Pengadilan Tipikor. Secara sederhana, alur penanganan perbuatan penyalahgunaan kewenangan karena jabatan dalam Tipikor sebelum adanya UU Administrasi Pemerintahan, apabila merujuk pada ketentuan dalam UU Pemberantasan Tipikor, UU KPK, UU Pengadilan Tipikor, dan KUHAP dapat digambarkan pada tabel berikut ini:

Sebaliknya, pihak-pihak yang berpendapat bahwa keberlakuan UU Administrasi Pemerintahan telah mereduksi kewenangan Peradilan Tipikor dalam menilai unsur menyalahgunakan kewenangan dalam Tipikor, mereka belum menemukan pola atau mekanisme baku dalam penanganan dugaan perbuatan menyalahgunakan kewenangan karena jabatan tersebut. Pihak-pihak yang berkepentingan justru melihat hal ini sebagai celah hukum untuk membebaskan diri dari jeratan Pasal 3 UU Pemberantasan Tipikor dengan melakukan berbagai upaya yang memungkinkan

Adanya Instruksi Presiden RI Nomor 1 Tahun 2016 tentang Percepatan Pelaksanaan Proyek Strategis Nasional dan Peraturan MARI Nomor 4 Tahun 2015 tentang Pedoman Beracara Dalam Penilaian Penyalahgunaan Wewenang yang sengaja dibentuk untuk mengisi kekosongan hukum acara dalam penilaian penyalahgunaan wewenang oleh Pengadilan TUN, bisa saja di baca sebagai upaya pemerintah dan MARI untuk mengatasi persoalan hukum yang timbul pasca diundangkannya UU Administrasi Pemerintahan.

Apabila merujuk pada ketentuan Pasal 17 jo. Pasal 21 ayat (1) jo. Pasal 1 angka 18 UU Administrasi Pemerintahan, kemudian dikaitkan Instruksi Presiden RI Nomor 1 Tahun 2016 dan Peraturan MARI Nomor 4 Tahun 2015, maka alur penanganan dugaan perbuatan menyalahgunakan kewenangan karena jabatan dalam Tipikor menjadi bertambah. Secara ringkas, alur penanganan perbuatan penyalahgunaan kewenangan karena jabatan dalam Tipikor pasca berlakunya UU Administrasi Pemerintahan dapat digambarkan pada tabel berikut ini: 
Ketika ada laporan mengenai dugaan adanya penyalahgunaan wewenang/ kewenangan karena jabatan yang ditujukan kepada Penyidik (KPK, Polri, dan Kejaksaan), maka hal pertama yang harus dilakukan oleh Penyidik sebelum melakukan penyelidikan dan/atau penyidikan adalah menyampaikan laporan tersebut kepada atasan/pimpinan pejabat/badan untuk dilakukan penilaian oleh APIP dan kemudian dilakukan pengujian oleh Pengadilan TUN. Setelah itu, apabila dinyatakan adanya penyalahgunaan wewenang/kewenangan, maka Penyidik dapat melakukan tugasnya untuk menilai aspek pidananya, yaitu dengan melihat means rea dan actus reus dari keputusan/ tindakan tersebut yang merupakan konsep utama menyalahgunakan kewenangan dalam Tipikor, ${ }^{55}$ kemudian berlanjut pada tahapan selanjutnya sesuai sistem peradilan pidana. Sebaliknya, ketika putusan Pengadilan TUN menyatakan tidak ada penyalahgunaan wewenang, maka penyidik tidak dapat melakukan penyelidikan dan/atau penyidikan terhadap kasus tersebut dan kasusnya berhenti disitu.

Namun demikian, Instruksi Presiden RI Nomor 1 Tahun 2016 dan Peraturan MARI Nomor 4 Tahun 2015 bukan tanpa persoalan. Instruksi Presiden RI Nomor 1 Tahun 2016 hanya berlaku bagi Kejaksaan Agung dan Polri sebagai organ pemerintahan yang berada di bawah dan bertanggungjawab kepada Presiden, tetapi tidak berlaku bagi KPK yang juga memiliki kewenangan atributif untuk melakukan penyelidikan dan/ atau penyidikan terhadap masalah tersebut. Selain itu, Instruksi Presiden RI Nomor 1 Tahun 2016, yang merupakan "policy rules" atau "beleidsregels" atau "quasi legislation" atau "pseudowetgeving" secara formal bukan peraturan perundang-undangan, sehingga tidak dapat melakukan pengecualian terhadap keberlakuan UU Administrasi Pemerintahan hanya terhadap proyek strategis nasional saja. UU Administrasi Pemerintahan merupakan aturan yang bersifat umum dan berlaku bagi semua warga Negara dan semua keadaan seperti diatur dalam undang-undang tersebut.

Persoalan berikutnya, dalam UU Administrasi Pemerintahan tidak terdapat batasan waktu yang limitatif bagi APIP sebagai bagian dari Peradilan TUN dalam melakukan tugasnya tersebut, batasan waktu biasanya diatur dalam petunjuk pelaksanaan APIP pada masing-masing badan/lembaga Negara yang tentunya berbeda satu dengan yang lainnya. Hal ini pastinya akan berdampak pada lamanya waktu penanganan kasus tersebut. Berbeda dengan pengujian ada tidaknya penyalahgunaan wewenang yang dilakukan oleh Pengadilan TUN yang yang dibatasi limitasi waktu (kurang lebih 42 hari kerja sejak permohonan diajukan).

55 Means rea merupakan keadaan jiwa atau pikiran (state of mind) yang terwujud bentuk niat yang salah atau niat jahat (guilty mind), sedangkan actus reus merupakan suatu perbuatan fisik (physical act) yang terwujud dalam bentuk tindakan yang salah (wrongful act). Lihat D. Andhi Nirwanto, "Arah Pemberantasan Korupsi...", op.cit., hlm. 19. 
Dalam Peraturan MARI Nomor 4 Tahun 2015 juga terdapat beberapa persoalan yang tidak kalah krusial, yaitu: Pertama, dalam pemeriksaan permohonan pengujian ada tidaknya penyalahgunaan wewenang ternyata pihaknya hanya Pemohon saja, sementaraAPIP yang hasil pengawasannya dijadikan sebagai objek permohonan dan seharusnya merupakan pihak yang paling mampu menjelaskan faktafakta dan bukti hasil pengawasan tersebut ternyata tidak dilibatkan. Kedua, pembatasan kewenangan Pengadilan TUN dalam menilai unsur penyalahgunaan wewenang, yaitu sebelum adanya proses pidana yang tidak jelas batasannya. Seharusnya ada kejelasan berkenaan dengan batasan proses pidana tersebut mulai dan sampai dimana, karena apabila berbicara tentang proses pidana, maka dimulai sejak adanya laporan dan/ atau pengaduan, penyelidikan, penyidikan, penuntutan, pemeriksaan di persidangan, hingga eksekusi di lembaga pemasyarakatan. Ketiga, definisi pemohon yang masih ambigu, khususnya yang dimaksud dengan Badan Pemerintahan sebagai pihak yang merasa dirugikan oleh hasil pemeriksaan APIP.Apakah hanya Badan Pemerintahan yang membuat keputusan/melakukan tindakan dan diduga melakukan penyalahgunaan wewenang, atau bisa juga Badan Pemerintahan lain yang berkepentingan dengan hasil pemeriksaan APIP, penegak hukum misalnya.
Berdasarkan uraian tersebut, maka dapat dilihat bahwa upaya pemerintah dan MARI untuk mengurai keruwetan mekanisme dalam penanganan penyalahgunaan wewenang karena jabatan masih menyisakan banyak persoalan. Oleh karena itu, maka perlu dilakukan penyempurnaan yang lebih komprehensif terhadap ketentuan-ketentuan terkait, khususnya di level undang-undang. Program Legislasi Nasional (Prolegnas) yang memasukkan RUU tentang Pemberantasan Tipikor dan RUU tentang KPK sebagai bagian dari Prolegnas yang akan diselesaikan dalam periode pemerintahan saat ini, ${ }^{56}$ bisa dijadikan jalan masuk untuk melakukan pembenahan terhadap persoalan-persoalan yang telah diuraikan di atas.

Legislatif perlu menegaskan sikapnya berkenaan dengan political will arah pemberantasan korupsi ke depan yang akan menyeimbangkan antara pendekatan preventif dengan pendekatan represif. Oleh karena itu, pendekatan represif yang dijadikan sebagai "primum remedium" harus ditinjau ulang. Hukum pidana harus dikembalikan kepada khittahnya sebagai senjata pamungkas dalam upaya penegakan hukum sesuai dengan asas "ultimum remedium".57

Apalagi dalam konteks Hukum Administrasi, keberadaan sanksi pidana menurut Barda Nawawi Arief, pada hakikatnya merupakan perwujudan dari

56 Dewan Perwakilan Rakyat Republik indonesia, "Daftar Prolegnas 2015-2019 angka 37 dan angka 63”, http:// www.dpr.go.id/uu/prolegnas-long-list, diakses 19 April 2016.

57 Suhariyono AR, "Perumusan Sanksi Pidana Dalam Pembentukan Peraturan Perundang-Undangan", Jurnal Perspektif VoL. XVII, No. 1, (Januari, 2012): 21. 
kebijakanmenggunakanhukumpidana sebagai sarana untuk menegakkan/melaksanakan hukum administrasi, ${ }^{58}$ sehingga berada pada tahapan terakhir. Hal ini seperti yang dikemukakan oleh W.F Prins yang dikutip Philipus M. Hadjon, ${ }^{59}$ bahwa hampir setiap peraturan berdasarkan hukum administrasi diakhiri dengan ketentuan pidana sebagai "in cauda venenum" (secara harfiah berarti: ada racun di ekor/buntut).

Setelah ada kesamaan perspektifmengenai keberlakuan UU Administrasi Pemerintahan, dikaitkan dengan UU Pemberantasan Tipikor, maka legislatif dapat melakukan penataan terhadap mekanisme penanganan masalah penyalahgunaan kewenangan dalam Tipikor, yang dapat dilakukan melalui langkahlangkah berikut ini:

Menegaskan kompetensi absolut Peradilan TUN yang diatur dalam Pasal 21 ayat (1) UU Administrasi Pemerintahan terhadap penilaian unsur penyalahgunaan kewenangan dalam Pasal 3 UU Pemberantasan Tipikor. Hal ini dapat dilakukan dengan penunjukan melalui sub-sub pasalnya atau melalui penjelasan dari pasal-pasal terkait;

Melakukan harmonisasi dan sinkronisasi terhadap hukum acara Tipikor, dengan melakukan penataan terhadap alur penanganan Tipikor "menyalahgunakan kewenangan" karena jabatan yang terdapat dalam UU Pemberantasan Tipikor, UU KPK, dan UU Pengadilan Tipikor serta UU terkait lainnya, agar terdapat kepastian dalam mekanisme penangan masalah tersebut. Hal ini bisa dilakukan dengan penunjukan melalui sub-sub pasalnya atau melalui penjelasan dari pasal-pasal terkait.

Melalui harmonisasi penanganan masalah penyalahgunaan kewenangan karena jabatan dalam Tipikor, maka hasil keputusan yang berbeda antara Peradilan TUN dan Peradilan Tipikor sebagai konsekuensi adanya dua dikotomi ranah hukum yang menangani dapat dihindarkan dan kebenaran (objectivity) yang komprehensif dapat dicapai. Adanya kepastian alur mekanisme penanganan masalah penyalahgunaan kewenangan karena jabatan dalam Tipikor akan membuat penanganannya menjadi efektif dan efisien sebagai prasyarat pemeriksaan dan penyelesaian perkara yang "sederhana". Kepastian mekanisme tersebut akan menutup jalan bagi para koruptor untuk melakukan berbagai eksperimen hukum guna mencari celah agar bisa lolos dari jerat hukum, sehingga biaya-biaya yang tidak perlu dapat dihindari dan waktu penyelesaian perkara menjadi lebih pasti. Kemudian, yang paling penting potensi terjadinya benturan kewenangan mengadili antara Peradilan Tipikor dan Peradilan Tipikor dapat dihindari.

58 Barda Nawawi Arief, Beberapa Aspek Kebijakan Penegakan dan Pengembangan Hukum Pidana, (Bandung: Citra Aditya, 2005), hlm. 139.

59 Philipus, M. Hadjon, dkk., Pengantar Hukum Administrasi Indonesia, (Yogyakarta: Gadjah Mada University Press, 2005), hlm. 245. 


\section{Simpulan}

Berdasarkan uraian pembahasan diatas, dapat disimpulkan bahwa:

1. Dalam memeriksa dan mememutus unsur menyalahgunakan kewenangan dalam tipikor pasca berlakunya UU Administrasi Nomor 30 Tahun 2014 adalah Peradilan Tipikor dan Peradilan TUN secara atributif sama-sama memiliki kompetensi absolut untuk memeriksa dan memutus penyalahgunaan kewenangan dalam Tipikor. Namun demikian, berdasarkan asas preferensi hukum "lex posteriori derogate legi priori”, kewenangan untuk memeriksa dan memutus unsur "menyalahgunakan kewenangan" karena jabatan dalam Tipikor menjadi kompetensi absolut Peradilan TUN.

2. Implikasi hukum Kebijakan legislasi yang memberikan kewenangan untuk memeriksa dan memutus penyalahgunaan kewenangan karena jabatan kepada Peradilan Tipikor dan Peradilan TUN, adalah:

a. Potensi timbulnya sengketa kewenangan mengadili (kompetensi absolut) penyalahgunaan kewenangan karena jabatan dalam Tipikor antara Peradilan Tipikor dan Peradilan TUN, karena dalam praktiknya asas preferensi hukum belum mampu menyelesaikan conflict of norm yang ada; b. Menimbulkan ketidakpastian hukum pada mekanisme penanganan Tipikor, karena adanya perbedaan perspektif dalam melihat keberlakuan UU Administrasi Pemerintahan terhadap kewenangan memeriksa dan memutus unsur "menyalahgunakan kewenangan" dalam Tipikor. Akibatnya proses peradilan Tipikor tidak lagi memenuhi asas peradilan sederhana, cepat, dan biaya murah, sehingga menghambat upaya pemberantasan Tipikor.

3. Kebijakan hukum dalam hal pengaturan ke depan agar masalah penyalahgunaan kewenangan karena jabatan tidak menjadi sengketa kewenangan mengadili antara Peradilan Tipikor dan Peradilan TUN, maka perlu dilakukan:

a. Penyamaan persepsi mengenai keberlakuan Pasal 21 ayat (1) jo. Pasal 1 angka 18 UU Nomor 30 tahun 2014 Administrasi Pemerintahan, terhadap penilaian penyalahgunaan kewenangan dalam Tipikor, dengan melakukan penyempurnaan terhadap peraturan perundangundangan terkait, khususnya dibidang pemberantasan Tipikor dan memberikan penegasan mengenai kompetensi absolut Peradilan TUN untuk memeriksa dan memutus unsur penyalahgunaan kewenangan dalam Tipikor dengan mencantumkan hal 
tersebut pada bagian penjelasan dari pasal-pasal terkait atau melalui penunjukan pada sub-sub pasalnya, utamanya Pasal 3 UU Pemberantasan Tipikor a. Penataan pada mekanisme penangannya Tipikor, khususnya Tipikor karena penyalahgunaan kewenangan dalam jabatan.

\section{DAFTAR PUSTAKA}

\section{Buku}

Arief, Barda Nawawi. Masalah Penegakan Hukum dan Kebijakan Penanggulangan Kejahatan. Bandung: Citra Aditya Bakti, 2001.

Chaerudin, dkk. Strategi Pencegahan \& Penegakan Hukum Tindak Pidana Korupsi. Cetakan Kedua. Bandung: Refika Aditama, 2009.

Chazawi, Adami. Hukum Pidana Materiil dan Formil Korupsi di Indonesia. Malang: Bayumedia, 2005.

Hadjon, M. Philipus, dkk. Pengantar Hukum Administrasi Indonesia. Yogyakarta: Gadjah Mada University Press, 2005. - Hukum Administrasi dan

Tindak Pidana Korupsi: Cetakan Kedua. Yogyakarta: Gajahmada University Press, 2012.

HR, Ridwan. Hukum Administrasi Negara, Edisi Revisi. Jakarta: RajaGrafindo Persada, 2014.

Kementerian Pendayagunaan Aparatur Negara dan Reformasi Birokrasi. Naskah Akademik Rancangan Undang-Undang tentang Administrasi Pemerintahan. Jakarta: Kemenpan RB, Tanpa Tahun.
Latif, Abdul. Hukum Administrasi Dalam Tindak Pidana Korupsi. Jakarta: Prenada Media Group, 2014.

Mulyadi, Lilik. Kompilasi Hukum Pidana Dalam Perspektif Teoritis dan Praktik Peradilan. Bandung: Mandar Maju, 2010.

Wiyono, R. Pembahasan Undang-Undang Pemberantasan Tindak Pidana Korupsi, Edisi Kedua. Jakarta: Sinar Grafika, 2012.

\section{Jurnal}

Alfitri. "Ideologi Welfare State dalam Dasar Negara Indonesia: Analisis Putusan Mahkamah Konstitusi Terkait Sistem Jaminan Sosial Nasional". Jurnal Konstitusi Vol. 9, No. 3, (September 2012): 458.

AR. Suhariyono. "Perumusan Sanksi Pidana Dalam Pembentukan Peraturan Perundang-undangan”. Jurnal Perspektif Vol. XVII, No. 1, (Januari, 2012): 21.

Fathudin. "Tindak Pidana Korupsi (Dugaan Penyalahgunaan Wewenang) Pejabat 
Publik (Perspektif Undang-undang Nomor 30 Tahun 2014 Tentang Administrasi Pemerintahan). Jurnal Cita Hukum Vol. II, No. 1, (Juni 2015): 129.

Mahmud, Mulyadi. "Penanggulangan Tindak Pidana Korupsi Dalam Perspektif Criminal Policy (Corruption Reduction In Criminal Policy Perspective)". Jurnal Legislasi Indonesia Vol. 8, No. 2, (Juni 2011): 219.

Susetio, Wasis. "Disharmoni Peraturan Perundang-Undangan Di Bidang Agraria”, Jurnal Lex Jurnalica Vol. 10, No. 3, (Desember 2013):145.

Syafrudin, Ateng. "Menuju Penyelenggaraan Pemerintahan Negara yang Bersih dan Bertanggungjawab". Jurnal Pro Justitia IV Universitas Parahyangan, Bandung: 22

Yulius, "Perkembangan Pemikiran dan Pengaturan Penyalahgunaan Wewenang di Indonesia (Tinjauan Singkat Dari Perspektif Hukum Administrasi Negara Pasca Berlakunya UndangUndang Nomor 30 Tahun 2014)". Jurrnal Hukum dan Peradilan Badan Penelitian dan Pengembangan Hukum dan Peradilan Mahkamah Agung RI Vol. 04, No. 3, (November 2015): 373.

\section{Makalah}

Nirwanto, D. Andhi. Arah Pemberantasan Korupsi Ke Depan (Pasca UndangUndang Administrasi Pemerintahan) disampaikan dalam Seminar Nasional dalam rangka H.U.T. IKAHI Ke-62 dengan tema "Undang-Undang Administrasi Pemerintahan, Menguatkan atau Melemahkan Upaya Pemberantasan Korupsi". Jakarta: Hotel Mercure Ancol, 2015.

Sitorus, Santer. Praktek Peradilan Penyelesaian Sengketa Administrasi Pemerintahan Berdasarkan UU Nomor 30 Tahun 2014 tentang Administrasi Pemerintahan, Slide Presentasi (PPT), disampaikan dalam Colloqium Membedah Undang-Undang Nomor 30 Tahun 2014 tentang Administrasi Pemerintahan. Surabaya: Garden Palace, 2015.

Santer Sitorus, 2015, Penyelesaian Sengketa Administrasi Pemerintahan Berdasarkan UUNomor 30 Tahun 2014 tentang Administrasi Pemerintahan, Slide Presentasi (PPT), disampaikan dalam Sosialisasi Undang-Undang Nomor 30 Tahun 2014 tentang Administrasi Pemerintahan. Jakarta: KemenPAN RB, 2015.

Sidharta. Penemuan Hukum Melalui Putusan Hakim, Makalah, disampaikan dalam Seminar Nasional Pemerkuatan Pemahaman Hak Asasi Manusia Untuk Hakim Seluruh Indonesia, yang diselenggarakan oleh Komisi Yudisial RI, PUSHAM UII, dan Norsk Senter For Menneskerettigheter Norwegian Centre For Human Rights. Medan: 
Hotel Grand Angkasa, 2011.

Thohary, Wahyudi dkk. Survey Persepsi Korupsi 2015. Laporan Penelitian. Tanpa Tempat Terbit: Danish Royal Embassy, 2015.

Fakrullah, Zudan Arif. Tindakan Hukum Bagi Aparatur Penyelenggara Pemerintahan, Makalah, disampaikan dalam Seminar Nasional dalam rangka H.U.T. IKAHI Ke-62 dengan tema "Undang-Undang Administrasi Pemerintahan, Menguatkan atau Melemahkan Upaya Pemberantasan Korupsi. Jakarta: Hotel Mercure Ancol, 2015.

\section{Disertasi}

Parmono, Budi. "Penyalahgunaan Wewenang Dalam Tindak Pidana Korupsi di Indonesia”. Disertasi Doktor Ilmu Hukum. Malang: Fakultas Hukum UB, 2011. Dipublikasikan

\section{Peraturan Perundang-Undangan}

Undang-Undang Republik Indonesia Nomor 5 Tahun 1986 tentang Peradilan Tata Usaha Negara, sebagaimana telah beberapa kali diubah terakhir dengan Undang-Undang Republik Indonesia Nomor 51 Tahun 2009.

Undang-Undang Republik Indonesia Nomor 31 Tahun 1999 tentang Pemberantasan Tindak Pidana Korupsi, sebagaimana telah diubah dengan Undang-Undang Republik Indonesia Nomor 20 Tahun
2001.

Undang-Undang Republik Indonesia Nomor 46 Tahun 2009 tentang Pengadilan Tindak Pidana Korupsi.

Undang-Undang Republik Indonesia Nomor 30 Tahun 2014 tentang Administrasi Pemerintahan.

Peraturan Mahkamah Agung RI Nomor 4 Tahun 2015 tentang Pedoman Beracara Dalam Penilaian Penyalahgunaan wewenang.

Instruksi Presiden RI Nomor 1 Tahun 2016 tentang Percepatan Pelaksanaan Proyek Strategis Nasional.

\section{Putusan Pengadilan}

Putusan MARI Nomor 977K/PID/2004, tanggal 10 Juni 2005.

Putusan MARI Nomor 979K/PID/2004, tanggal 10 Juni 2005.

Putusan MARI Nomor 14/Pid.Sus /2012/ PN.AB., tanggal 4 September 2012.

Putusan MARI Nomor 03/PID.SUS/ TIPIKOR/2013/PN.PBR., tanggal 1 Mei 2013.

Putusan MARI Nomor 1485K/Pid.Sus/2013, tanggal 2 Oktober 2013.

Putusan Pengadilan Negeri Jakarta Selatan Nomor 32/Pid.Prap/2015/PN.Jkt.Sel., tanggal 12 Mei 2015.

Putusan Hakim Pengadilan Tanjung Pinang Nomor 2/Pid.Sus-TIPIKOR/2015/ PN.Tpg, tanggal 11 Juni 2015.

Putusan Hakim Pengadilan Tanjung Pinang Nomor 3/Pid.Sus-TIPIKOR/2015/ 
PN.Tpg, tanggal 11 Juni 2015.

Putusan Pengadilan Negeri Jakarta Selatan

Nomor 55/Pid.Prap/2015/PN.Jkt.Sel., tanggal 9 Juli 2015.

Putusan Pengadilan Tinggi TUN Medan Nomor 176/B/2015/PT TUN-MDN, tanggal 21 Desember 2015.

\section{Naskah Internet}

Detik.com, "UU Administrasi Pemerintahan Dinilai Mengudeta Pemberantasan Korupsi”. http://news.detik.com/ berita/2873765/uu-administrasipemerintahan-dinilai-mengudetapem-berantasan-korupsi. Diakses 28 Februari 2016.

Dewan Perwakilan Rakyat Republik Indonesia. "Daftar Prolegnas 20152019 angka 37 dan angka 63". http:// www.dpr.go.id/uu/prolegnas-long-list. Diakses 19 April 2016.
KBBI. "Arti dari Wenang”. kbbi.web.id/ wenang. Diakses 6 Desember 2015.

KBBI. "Arti dari Salah Guna. Menyalahgunakan”. kbbi.web.id/ salah\%20guna.menyalahgunakan. Diakses 8 Maret 2016.

KBBI. "Arti dari Hak". kbbi.web.id/hak. Diakses 14 Maret 2016.

KBBI. “Arti dari Kuasa”. kbbi.web.id/kuasa. Diakses 14 Maret 2016.

\section{Kamus}

Black, Henry Campbell. Black's Law Dictionary, Revised Fourth Edition. ST. Paul, Minn: West Publishing, 1968. Moeimam, Susi dan Hein Steinhauer. Kamus Belanda-Indonesia. Jakarta: Gramedia Pustaka, 2005.

Bull, Victoria. Oxford Learner's Pocket Dictionary: Fourth Edition. Oxford: Oxford University Press, 2012. 